\title{
NEW BIOEMULSIFIERS PRODUCED BY CANDIDA LIPOLYTICA USING D-GLUCOSE AND BABASSU OIL AS CARBON SOURCES
}

\author{
Mabel H. Vance-Harrop ${ }^{1,2}$; Norma B. de Gusmão ${ }^{2,3}$; Galba Maria de Campos-Takaki ${ }^{2,4,5 *}$ \\ ${ }^{1}$ Laboratório de Apoio Animal, Ministério da Agricultura Pecuária e do Abastecimento; ${ }^{2}$ Doutorado em Biologia de Fungos, \\ Universidade Federal de Pernambuco; ${ }^{3}$ Departamento de Antibióticos, Universidade Federal de Pernambuco; ${ }^{4}$ Departamento de \\ Química, ${ }^{5}$ Núcleo de Pesquisas em Ciências Ambientais, Universidade Católica de Pernambuco, Recife, PE, Brasil
}

Submitted: June 20, 2001; Returned to authors for corrections: April 17, 2001; Approved: May 06, 2003

\begin{abstract}
Candida lipolytica IA 1055 produced extracellular biosurfactants with emulsification activity by fermentation using babassu oil and D-glucose as carbon sources. Natural seawater diluted at 50\% supplemented with urea, ammonium sulfate, and phosphate was used as economic basal medium. The best results were achieved

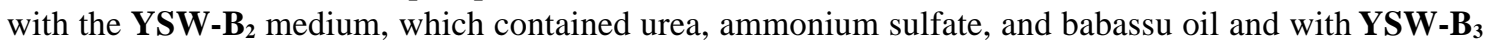
medium, which contained urea, ammonium sulfate, phosphate, and babassu oil, kept under fed batch fermentation for 60 hours with $5 \%$ of babassu oil. For the two media, the maximum specific growth rates were $0.02 \mathrm{~h}^{-1}$ and $0.04 \mathrm{~h}^{-1}$; the generation times were $34.6 \mathrm{~h}^{-1}$ and $17.3 \mathrm{~h}^{-1}$, and the emulsification activities were 0.666 and 0.158 units, respectively. The molecules of these new bioemulsifiers were contituted of carbohydrates, proteins and lipids.
\end{abstract}

Keywords: Bioemulsifier, Candida lipolytica, seawater, babassu oil

Biosurfactants are amphiphilic molecules consisting of a hydrophilic and a hydrophobic domains. These compounds are capable of reducing surface and interfacial tension between liquids, solids and gases, allowing them to mix or disperse readily as emulsions in water or other liquids. Microbial compounds that are capable to exhibit particularly high surface activity and emulsifying activity are classified as biosurfactants (1). A number of microorganisms are excellent sources of potentially useful amphipatic biopolymers, for instance Acinetobacter radioresistens (5); Candida bombicola $(9,13)$, and Yarrowia lipolytica (14).

Bioemulsifiers are biodegradable and can be produced from renewable and cheap subtracts. Native vegetable oils have been used as carbon source and seawater as media component for production of biosurfactants by Candida lipolytica. This paper reports the results attained on bioemulsifier production through the use of economic subtracts in seawater media supplemented with babassu oil, and D-glucose as control.
Candida lipolytica IA 1055 was obtained from the culture collection of the Departamento of Antibióticos of Universidade Federal de Pernambuco. Stock cultures of the organism were maintained at $4^{\circ} \mathrm{C}$ on Yeast Mold Agar slants containing yeast extract $(0.3 \%)$; malt extract $(0.3 \%)$; D-glucose $(1.0 \%)$; tryptone $(0.5 \%)$; and agar $(1.5 \%)$.

Carbon sources utilized throughout the study were 5\% babassu oil and $1 \%$ D-glucose, added to a basal medium called Yeast Salt Water (YSW). Growth media were prepared as follows: YSW-G-ammonium sulfate $0.1 \mathrm{gl}^{-1}$, D-glucose $1 \mathrm{gl}^{-1} ; \mathbf{Y S W}-\mathbf{G}_{1}-$ ammonium sulfate $0.1 \mathrm{gl}^{-1}$, urea $0.1 \mathrm{gl}^{-1}$, D-glucose $1 \mathrm{gl}^{-1} ; \mathbf{Y S W}-\mathbf{B}_{2}$ -urea $0.25 \mathrm{gl}^{-1}$; acid phosphate of potassium $1.36 \mathrm{gl}^{-1}$, babassu oil $5 \mathrm{ml}^{-1}$; and $\mathbf{Y S W}-\mathbf{B}_{3}-$ ammonium sulfate $0.1 \mathrm{gl}^{-1}$, urea $0.25 \mathrm{gl}^{-1}$, and acid phosphate of potassium $1.36 \mathrm{gl}^{-1}$, and babassu oil $5 \mathrm{ml}^{-1}$.

The media were diluted 1:1 (v/v) in distilled water and natural seawater $(\mathrm{NaCl}$ final concentration $13 \%)$; the $\mathrm{pH}$ was set to $5.3 \pm 0.2$, followed by sterilization at $121^{\circ} \mathrm{C}$ for 15 minutes. The seawater used as basal medium was collected in Boa Viagem

\footnotetext{
* Corresponding author. Mailing address: Departamento de Química, Núcleo de Pesquisas em Ciências Ambientais, Universidade Católica de Pernambuco. Rua Nunes Machado, 42, Boa-Vista. 500050-590, Recife, PE, Brasil. E-mail: takaki@unicap.br
} 
beach, and the salinity was determined by the Mohr-Knudsen method as described in Strickland and Parsons (11).

Cells grown in Yeast Mold Broth were used as inoculum $(1 \%, \mathrm{v} / \mathrm{v})$. The fermentation process was carried out in $1000 \mathrm{ml}-$ Erlenmeyer flasks, containing $300 \mathrm{ml}$ of medium. The flasks were incubated at $28^{\circ} \mathrm{C}$ on an orbital shaker at $150 \mathrm{rpm}$ for 240 hours. After 60 hours of fermentation, $5 \%$ of babassu oil was added to the medium.

Aliquots of $7 \mathrm{ml}$ of the culture were collected every 24 hours for $\mathrm{pH}$ measurement using a potentiometer and for counts of viable cells, determined by spreading $0.1 \mathrm{ml}$ of the appropriate dilution onto Yeast Mold Agar. Colony counts were performed after incubation at $28^{\circ} \mathrm{C}$ for 48 hours.

The specific growth rate was measured according to Pirt (8).

In order to determine the emulsification activity, aliquots of $2 \mathrm{ml}$ of the cultures submitted to filtration through a $0.22 \mu \mathrm{m}$ Millipore membrane filter were mixed with $2 \mathrm{ml}$ of $0.1 \mathrm{M}$ sodium acetate buffer $(\mathrm{pH} 3.0)$ and $1 \mathrm{ml}$ of $\mathrm{n}$-hexadecane in a screwcapped tube. The mixture was then homogeneized in a vortex for 2 minutes at $25^{\circ} \mathrm{C}$. After 10 minutes, the absorbance was measured at 540nm in a spectrophotometer. The blank consisted in $2 \mathrm{ml}$ of sterile YSW medium. One unit of emulsification activity was defined as the amount of emulsifier that resulted in an absorbance of 1.0 at $540 \mathrm{~nm}$ (2).

For partial purification of the bioemulsifier, yeasts cells were removed from bioemulsifier-containing media, by filtration through a Whatman $n^{\circ} 1$ paper and then through a $0.22 \mu \mathrm{m}$ Millipore membrane filter.

The cell-free filtrate was dialyzed against deionized water, (five changes) and then concentrated by lyophilization. The concentrate was treated twice with chloroform-methanol $(2: 1$, $\mathrm{v} / \mathrm{v})$ at $25^{\circ} \mathrm{C}$. The solvents were removed by evaporation. The white precipitate formed in the aqueous phase was collected in Whatman no. 42 filter paper and dried. The dry material was redissolved in ultra pure water for analytical determinations.

The bioemulsifiers produced by $C$. lipolytica were submitted to determination of the total amount of carbohydrates, proteins and lipids, using colorimetric methods (LABTEST Diagnostic ${ }^{\circledR}$ Brazil).

After 41 hours, the cell concentration in YSW-G medium was $1.0 \times 10^{6} \mathrm{CFU} / \mathrm{ml}$. After 50 hours, a diauxic behavior was observed. The number of cells after 89 hours decreased to $3.2 \times 10^{2} \mathrm{CFU} / \mathrm{ml}$ and the specific growth rate was $\mu_{\max }=0.04 \mathrm{~h}^{-1}$. During fermentation course, the $\mathrm{pH}$ dropped from 4.8 after 17 hours to 2.7 at the end of the growth, suggesting that fermentation is controlled by $\mathrm{pH}$ (Fig. A). The cell concentration in $\mathrm{YSW}_{\mathrm{S}} \mathrm{G}_{1}$ medium, which corresponds to YSW-G medium plus $1 \%$ urea, after 23 hours of cultivation was $1.1 \times 10^{6} \mathrm{CFU} / \mathrm{ml}$. The peak was obtained after 168 hours of fermentation, with $6.0 \times 10^{6} \mathrm{CFU} / \mathrm{ml}$. There was a growth decrease after 192 hours. The kinetics parameters were a maximum specific growth rate of $\mu_{\max }=0.05 \mathrm{~h}^{-1}$ and generation time of 13.8 hours. After 23 hours of fermentation the $\mathrm{pH}$ was 8.04, and 7.04 in the end of the process, and the emulsification activities were 0.030 , and 1.717 units, respectively (Fig. 1B).

The growth decrease of $C$. lipolytica was probably due to the addition of urea, which increased the $\mathrm{pH}$ of the medium. Cooper and Paddock (3) observed that Torulopsis bombicola growth decreased when urea was used instead of yeast extract in media with glucose and vegetable oils. Other microbial emulsifiers (sophorose lipids) have been synthesized by degradation of insoluble substrates such as vegetable oils or soluble substrates, like carbohydrates, as carbon sources, utilizing inexpensive media $(6,12,13)$.

In this study, the YSW-G medium was the most effective for growth of Candida lipolytica. This result with the medium YSW supplemented with glucose without urea is corroborated by Cooper and Paddock $(3,10)$.

After 48 hours of cultivation, $3.1 \times 10^{2}$ viable cells were observed in YSW-B ${ }_{2}$ medium. The maximum number of cells was attained after 144 hours, with $1.8 \times 10^{7} \mathrm{CFU} / \mathrm{ml}$. The $\mathrm{pH}$ was 7.5 in the first stage $(48 \mathrm{~h})$ of the fermentation, and decreased to 5.6 in the end. The maximum specific growth rate was $\mu_{\max }=0.02 \mathrm{~h}^{-1}$, the generation time was $34.6 \mathrm{~h}^{-1}$, and the emulsification activity was 0.666 units (Fig. 1C).

After 64 hours of fermentation $C$. lipolytica cultivated in the medium YSW-B 3 showed $2.8 \times 10^{5} \mathrm{CFU} / \mathrm{ml}$. The maximum number of viable cells occurred after 168 of cultivation. At the beginning of the process $(24 \mathrm{~h})$, the $\mathrm{pH}$ was 6.4 , decreasing to 5.9 after 168 hours. A maximum specific growth rate of $\mu_{\max }=0.04 \mathrm{~h}^{-1}$, generation time of $17.3 \mathrm{~h}^{-1}$, and 0.158 units of emulsification activity were observed (Fig. 1D).

Johnson (4) reported that the maximum emulsification activity in Rhodotorula glutinis was achieved in the presence of $\mathrm{KNO}_{3}$, followed by ammonium salt and urea. Our study with $C$. lipolytica showed that urea as an additional nitrogen source in the two tested media did not cause any decrease in growth rate when batch fermentation at exponential phase was used. These results suggested a decrease in the interfacial tension of babassu oil-containing YSW-B $\mathrm{B}_{2}$ and $\mathrm{YSW}-\mathrm{B}_{3}$ media caused by $C$. lipolytica, presumably due to release of fatty acids in the initial stages of fermentation. The production of fatty acids declines after $60 \mathrm{~h}$ of fermentation, but the interfacial tension continues.

The bioemulsifiers obtained from YSW-G and YSW-B ${ }_{3}$ media were composed by proteins ( 54.3 and $43.0 \% \mathrm{w} / \mathrm{v}$ respectively), carbohydrates (35.5 and $40.0 \%$ w/v respectively) and lipids (8.4 and $16.0 \% \mathrm{w} / \mathrm{v}$ respectively).

The high production of emulsifiers in both media was probably caused by the presence of potassium phosphate. Palejwala and Desai (7) observed the influence of phosphate anions in the medium on the production of emulsifiers. It should be noticed that emulsifiers were produced in the two examined media (YSW-B ${ }_{2}$ and YSW-B S $_{3}$ using low-cost substrates (babassu oil and seawater), which can be used for bioemulsifier production by Candida lipolytica. 


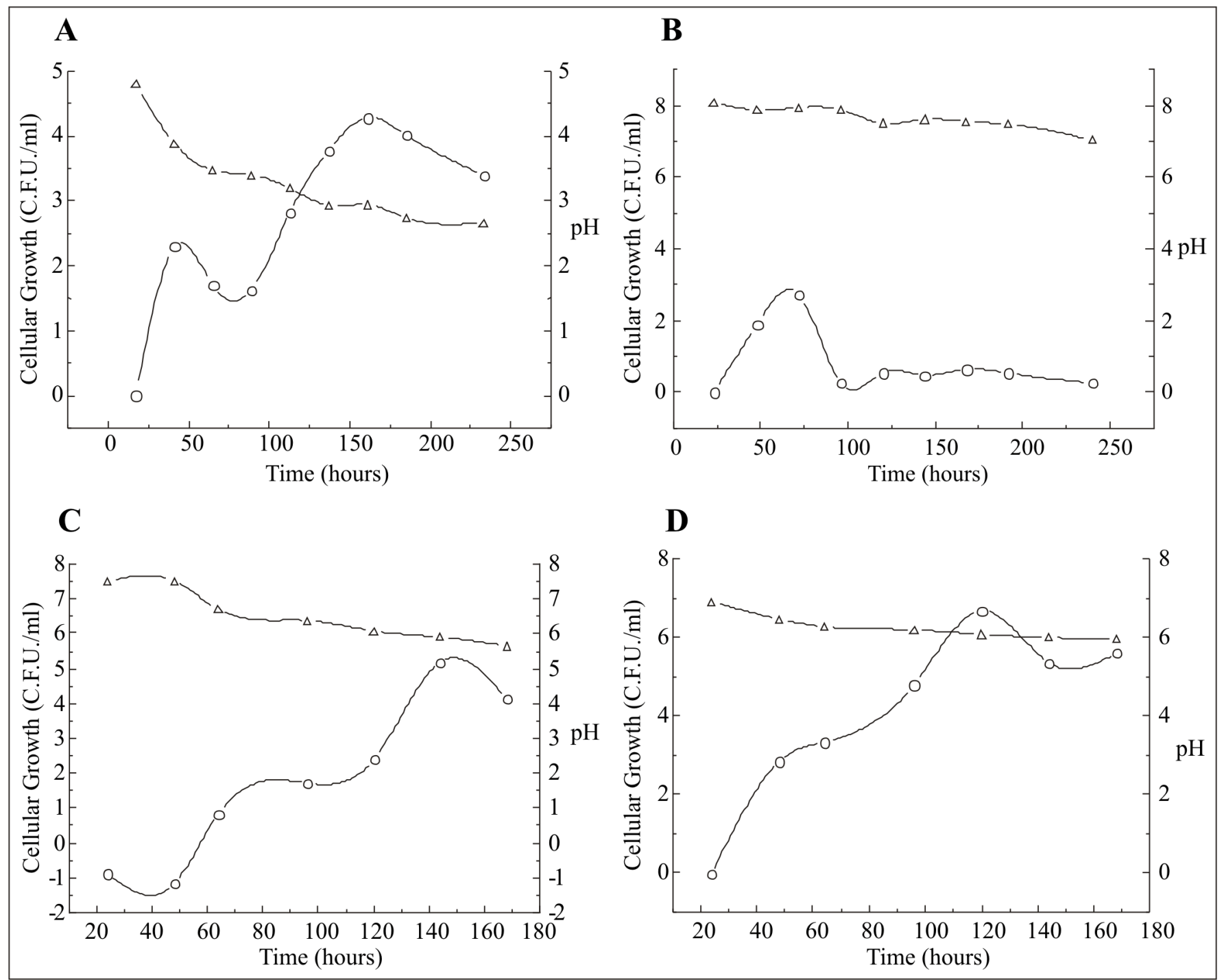

Figure 1. Growth (O) of Candida lipolytica and $\mathrm{pH}(\triangle)$ of $\mathrm{YSW}-\mathrm{G}(\mathrm{A}), \mathrm{YSW}-\mathrm{G}_{1}(\mathrm{~B}), \mathrm{YSW}-\mathrm{B}_{2}(\mathrm{C})$ and $\mathrm{YSW}-\mathrm{B}_{3}(\mathrm{D})$ media incubated at $28^{\circ} \mathrm{C}$ for 240 hours, $150 \mathrm{rpm}$.

\section{ACKNOWLEDGEMENTS}

Study supported by grants from CNPq, PRONEX, FINEP/ CETPETRO and UNICAP.

\section{RESUMO}

\section{Novos bioemulsificantes produzidos por Candida lipolytica usando D-glicose e óleo de babaçu como fontes de carbono}

Candida lipolytica IA 1055 produziu biosurfactantes extracelulares com atividade de emulsificação, através de fermentação utilizando óleo de babaçu e D-glicose como fontes de carbono. A água do mar diluída a 50\% suplementada com uréia, sulfato de amônio e fosfato foi usada como meio basal. Os melhores resultados foram atingidos com os meios YSW- $\mathrm{B}_{2}$ (contendo uréia, sulfato de amônio e óleo de babaçu)e YSW-B 3 (contendo uréia, sulfato de amônio, fosfato e óleo de babaçu), através de fermentação em batelada alimentada com 5\% de óleo de babaçu. A velocidade específica de crescimento foi de 0,02 $\mathrm{h}^{-1}$ e $0,04 \mathrm{~h}^{-1}$; tempo de geração de $34,6 \mathrm{~h}^{-1}$ e $17,3 \mathrm{~h}^{-1}$ e atividade de emulsificação igual a 0,666 e 0,158 unidades, respectivamente. As moléculas dos novos bioemulsificantes demonstraram ser constituídas por carboidratos, proteínas e lipídeos.

Palavras-chave: Bioemulsificante; Candida lipolytica; óleo de babaçu, água do mar 


\section{REFERENCES}

1. Banat, I.M.; Makkar, R.S.; Cameotra, S.S. Potential commercial applications of microbial surfactants. Appl. Microbiol. Biotechnol., 53: 495-508, 2000.

2. Cirigliano, M.C.; Carman, G.M.. Isolation of a Bioemulsifier from Candida lipolytica. Appl. Environ. Microbiol., 48: 747-750, 1984.

3. Cooper, D.G.; Paddock, D.A. Production of a Biosurfactant from Torulopsis bombicola. Appl.Environ. Microbiol., 47: 173-176, 1984.

4. Johnson, V.; Singh, M.; Saini, V.S. Bioemulsifier Production by an Oleaginous Yeast Rhodotorula glutinis IIP-30. Biotechnol. Lett., 14: 487-490, 1992.

5. Navon-Venezia, S.; Zosim, Z.; Gottlieb, A.; Legmann, R.; Carmeli, S.; Ron, E.Z.; Rosenberg, E. Alasan a New Bioemulsifier from Acinetobacter radioresistens. Appl. Environ. Microbiol., 61: 3240-3244, 1995.

6. Noordman, W.H.; Wachter, J.H.J.; Boer, G.J.; Janssen, D.B. The enhancement by surfactants of hexadecane degradation by Pseudomonas aeruginosa varies with substrate availability. $J$. Biotechnol., 94(2): 195-212, 2002.

7. Palejwala, S.; Desai, J.D. Production of an Extracellular Emulsifier by a Gram Negative Bacterium. Biotechnol. Lett., 2: 115-118, 1989.
8. Pirt, S.J. Principles of Microbe and cell cultivation. London, Blackwell Scientific Publications, 1975.

9. Rau, U.; Manzke, C.; Wagner, F. Influence of Substrate Supply on the production of sophrose lipids by Candida lipolytica ATCC 22214. Biotechnol. Lett., 18: 149-154, 1996.

10. Sarubbo, L.A.; Marçal, M.C.; Neves, M.L.; Porto, A.L.; CamposTakaki, G.M. Bioemulsifier production in batch culture using glucose as carbon source by Candida lipolytica. Appl. Biochem. Biotechnol. 95(1): 59-67, 2001.

11. Strickland, J.D.H.; Parsons, T.R. A Manual of Sea Water Analysis Canada, Bulletin Fisheries Research Board, 1965.

12. Zhou, Q.H.; Kosaric, N. Effect of Lactose and Olive Oil on Intra and Extracellular lipids of Torulopsis bombicola. Biotechnol. Lett., 15: 477-482, 1993.

13. Zhou, Q.H.; Kosaric, N. Utilization of Canola Oil and Lactose to produce Biosurfactant with Candida bombicola. JAOCS., 72: 67$71,1995$.

14. Zinjarde, S.; Chinnathambi, S.; Lachke, A.H.; Pant, A. Isolation of an Emulsifier from Yarrowia lipolytica NCIM 3589 using a Modified Mini Isoelectric Focusing Unit. Lett. Appl. Microbiol., 24: 117-121, 1997. 